\title{
Demand for Money in China with Currency Substitution: Evidence from the Recent Data
}

\author{
Yongqing Wang \\ Department of Business and Economics, University of Wisconsin-Waukesha, Waukesha, WI, USA \\ Email: yongqing.wang@uwc.edu
}

How to cite this paper: Wang, Y.Q. (2017) Demand for Money in China with Currency Substitution: Evidence from the Recent Data. Modern Economy, 8, 484-493. https://doi.org/10.4236/me.2017.84036

Received: January 19, 2017

Accepted: April 4, 2017

Published: April 7, 2017

Copyright $\odot 2017$ by author and Scientific Research Publishing Inc. This work is licensed under the Creative Commons Attribution International License (CC BY 4.0).

http://creativecommons.org/licenses/by/4.0/

\begin{abstract}
China has undertaken numerous economic reforms since 1978, including the abolishment of the fixed exchange rate system and adoption of a "managed floating exchange rate" regime in 2005. In the present study, we examined money demand in China by employing quarterly data after China adopted the new exchange rate system (from 2006Q1 to 2016Q1). To consider currency substitution, demand for money that includes exchange rate in addition to income and inflation is estimated. By incorporating the CUSUM and CUSUMSQ tests for stability in conjunction with cointegration analysis, we find M2 is a better measurement of monetary aggregate because it is cointegrated with its determinants and it is also stable. We also find strong evidence of currency substitution for M2.
\end{abstract}

\section{Keywords}

Money Demand, Currency Substitution, Cointegration, Stability, CUSUM and CUSUMQ

\section{Introduction}

Money demand is a crucial macro topic because it forms the link between the monetary aggregates and some important macro variables. Money demand in many countries has been extensively studied. Following other countries, money demand in China also attracts a lot of attention, especially after 1980's. This is because China has undergone dramatic economic reforms since 1978, resulting in rapid growth of the economy. Currently, China has become the world's second largest economy in terms of nominal gross domestic product (GDP).

The literature on money demand in China includes but is not limited to [1] [2] [3] [4] [5]. In general, the previous literature has employed standard estimation technique or cointegration techniques to estimate money demand in China from different aspects such as the definition of monetary aggregate, the variables 
that should be included in the money demand function, the effects of economic reform on money demand, and the causal relationship between monetary aggregate and some other macroeconomic variables. In the study [1], they use quarterly data over the period of 1983Q1-2002Q4 and employ CUSUM and CUSUMSQ stability tests in bounds testing approach for cointegration to analyze money demand in China. In addition to income and domestic interest rate, foreign interest rate and exchange rate are incorporated into the model. The coefficients for both foreign interest rate and exchange rate are not significant, indicating the foreign sector does not play a significant role in money demand in China during the period of 1983 to 2002. They find that M1 monetary aggregate in China is stable, while the stability of M2 monetary aggregate is somewhat questionable. Interestingly, in [3], annual data from 1997 to 2006 were used and they find both M1 and M2 are stable.

These studies have helped us understand money demand in China. However, there are several limitations. First, there is almost no paper reporting effects of possible currency substitution on money demand in China. Currency substitution occurs if the domestic people hold foreign currencies in place of the domestic currency. Typically, when a currency either depreciates or appreciates, domestic people will try to protect their wealth by currency substitution. The depreciation of domestic currency may increase demand for money if the depreciation increases the wealth since the value of foreign assets measured in domestic currency will be higher. But depreciation may lower the demand for money if the public try to increase the value of assets by increasing the holdings of foreign currencies to avoid further domestic currency depreciation. China has gradually opened up to the world since 1978 and currency substitution may have important effects on money demand in China, which has been ignored in most previous studies. This is probably because China was under fixed exchange rate before 2005. Second, the stability of money demand is vital for effective monetary policies and for the economy. As demonstrated by [6], cointegration does not imply stability. The CUSUM and CUSUMQ stability test can be used to test the stability of demand for money. Moreover, it has been suggested that money demand would be less stable if currency substitution exists since domestic monetary policy will be affected by foreign economic variables. This argument makes it even more important to test the long-run stability of money demand, especially when the exchange rate is included into the model. Third, the data used in most of the previous studies cover from 1980 and up to 2000s. However, Chinese reform has been undertaken for more than 40 years now and major changes have continued to take place in Chinese economy after 2000. The properties of money demand in China based on the most recent data might be different.

Thus, the purpose of the present study is to examine the possible effects of currency substitution on demand for money in China based on the most recent data and to test its stability. To this end, Section 2 provides a brief overview of the recent banking system reform and exchange rate reform. Section 3 formulates the model of demand for money and introduces the bound testing ap- 
proach to cointegration technique. Section 4 presents the empirical results and Section 5 concludes.

\section{The Reform of Banking System and Exchange Rate}

Since 1978, China has gradually undergone a transition from regulation over financial instruments to liberalization of its financial markets. According to [7], the reform of banking system in China has gone through 3 stages so far. During the first stage (1978 to 1992), China abolished mono-banking system, while established new banks and securities markets. In the second stage (1993 to 1997), the concept of the "socialist market economy" was introduced. Laws and regulations are enforced while the financial markets are developed. In the third stage (after 2002), the further reform and opening are promoted. The third stage reform focuses on the capital and assets structure of commercial banks as well as the rural financial system.

China was under strict capital control before 1998. Prior to 1998, Chinese financial and banking sector lacked market-oriented policies because banks in China were tightly controlled by the government. Meanwhile, the banks in China did not have enough capital. Moreover, the amount of nonperforming loans was enormous because banks in China had to finance state-owned enterprises to fulfill the government policy goals without much consideration of its own profitability or risk. To solve the first problem, in 1998, bank's credit plan was abolished and more market-oriented policies, such as liberalization of interest rate, were introduced. To solve the other two problems, the government has recapitalized banks and taken part of nonperforming loans off their books. In 1998, 270 billion Yuan of special-purpose bonds were issued by Chinese Ministry of Finance (MOF) to inject fresh capital to the four major banks (People's Bank of China, Bank of China, Agricultural Bank, and China Construction Bank). In 1999, 4 state-owned Asset Management Companies were set up. Between 1999 and 2000, 1394 billion of Yuan nonperforming loans from the four major banks were transferred to the Asset Management Companies. At the end of 2003, 45 billion US\$ were injected to the Bank of China and the China Construction Bank. The four major banks started their restructuring in 2004 and the financial service industry in China was fully opened to foreign sectors in 2006.

The changes described above suggest that Chinese banking sector has changed significantly. Through these reforms, China has gradually formed a diversified system including banking and non-banking, domestic and foreign institutions, and the policies are more market-oriented. As a result, the variables that should be included in the demand for money in China and the appropriate definition of monetary aggregate may be more in line with the traditional demand for money function.

Further, China adopted the fixed exchange rate before 2005. When the exchange rate is fixed, the effect of exchange rate on the demand for money is trivial since it is hard for the domestic people to increase nominal value of wealth by increasing the holding of foreign currencies. However, China moved to a 
"managed floating exchange rate regime" in July 2005, which allowed Chinese exchange rate to float within certain percentage based on market supply and demand with reference to a basket of currencies. The exchange rate was 8.19 Yuan/\$ in 2005, 7.97 Yuan/\$ in 2006, and 7.61 Yuan/\$ in 2007. Currently, it is about $6.77 \mathrm{Yuan} / \$$. The more market-oriented exchange rate may have some effects on money demand in China. We are able to take this into consideration if more recent data are used.

On one hand, given the substantial reform in the banking system, it is possible that demand for money in China have different characteristics if more recent data are used. On the other hand, currency substitution may occur because of the more market-oriented exchange rate system. Considering this important possibility, we analyze demand for money in China by the quarterly data after China adopted the new exchange rate regime, from 2006Q1 to 2016Q1.

\section{Model Specification and the Bound Testing Approach}

Following the previous literatures, money demand of a country depends on transaction demand for money, which is usually measured by the domestic income. Despite the reforms, Chinese interest rate is still not completely marketoriented and it is not a good measurement of opportunity costs of holding money. Previous studies such as [4] argue that inflation rate is a better measurement of opportunity costs of holding money in China. Hence, inflation rate is chosen to measure the opportunity costs of holding money in present study. In order to consider the possible currency substitution, exchange rate is included into the model. The modified money demand model is outlined by Equation (1):

$$
\operatorname{Ln} M_{t}=a+b Y_{t}+c \pi_{t}+d E X_{t}+\varepsilon_{t}
$$

where $M$ is the Chinese monetary aggregate; $Y$ is the real income in China; $\pi$ is the domestic inflation rate, and $E X$ is the nominal exchange rate. Two definitions of monetary aggregate are used: M1 is the narrow money in nominal term, while M2 is the broad money in nominal term. $Y$ is measured by the quarterly Real GDP index. The domestic inflation rate is defined as percentage change corresponding period previous year (\%) and the nominal exchange rate is defined as number of Chinese currency Yuan per US dollar. All data are from International Financial Statistics Database by International Monetary Fund (IMF).

Regarding the sign of the coefficients, we expect $b$ to be positive, $c$ to be negative, while $d$ could be either positive or negative. The reasons are as following. As real income increases, the transaction demand for money usually rises. Thus, demand for money will increase as real income increases. Hence, an estimate of the coefficient of real income $Y(\mathrm{~b})$ is expected to be positive. As domestic inflation rate increases, the demand for money will decrease since the opportunity costs of holding money is higher. So, an estimate of coefficient of domestic inflation rate $\pi(c)$ is expected to be negative. A change in exchange rate $(E X)$ usually has two effects. Note that in this paper, exchange rate is defined as number of Chinese currency Yuan per US\$. Under this definition, an increase in $E X$ implies 
a depreciation of domestic (Chinese) currency or an appreciation of foreign country currency. On one hand, depreciation of domestic currency increases the value of foreign assets held by domestic people measured in domestic currency. Thus, it increases the wealth and the demand for domestic currency. If this wealth effect dominates, $d$ should be positive. On the other hand, when a currency depreciates, the public tend to increase holdings of foreign currency and decrease holdings of domestic money. By doing so, the domestic residents try to increase the asset by avoiding further domestic currency depreciation. If this substitute effect dominates, $d$ should be negative.

Equation (1) states the long-run relationship among the variables. Although this study focuses on money demand in China in the long-run, we should also incorporate the short-run dynamic of Equation (1) in order to carry out the testing procedure. Following [9], it takes following form:

$$
\begin{aligned}
\Delta \operatorname{Ln} M_{t}= & \alpha+\sum_{k=1}^{n} \beta_{0, k} \Delta \operatorname{Ln} M_{t-k}+\sum_{k=0}^{n} \beta_{1, k} \Delta Y_{t-k}+\sum_{k=0}^{n} \beta_{2, k} \Delta \pi_{t-k}+\sum_{k=0}^{n} \beta_{3, k} \Delta E X_{t-k} \\
& +\delta_{0} \operatorname{Ln} M_{t-1}+\delta_{1} Y_{t-1}+\delta_{2} \pi_{t-1}+\delta_{3} E X_{t-1}+\mu_{t}
\end{aligned}
$$

The null hypothesis of no cointegration $\left(\delta_{0}=\delta_{1}=\delta_{2}=\delta_{3}=0\right.$ ) is tested against the alternative hypothesis $\left(\delta_{0} \neq \delta_{1} \neq \delta_{2} \neq \delta_{3} \neq 0\right)$. Unlike the Error Correction Model by Engle-Granger [8], [9] introduces a technique that does not require pre-unit root testing. In order to justify cointegration among variables in (2), [9] applies the F-test with new critical values that they calculate. Upper bound of critical values is calculated assuming that all variables are integrated of order one, while lower bound of critical values is calculated assuming that all variables are integrated of order zero. If F-test statistic is below the lower bound, the null hypothesis of no level effect can't be rejected. If the F-test statistic lies between the bounds, the test is inconclusive. Only when it is above the upper bound, the null hypothesis of no level effect is rejected, suggesting cointegration among the variables in the equation. Moreover, the negative and significant error-correction term is also an efficient indicator of cointegration. If there is cointegration, the CUSUM and CUSUMSQ tests will be applied to the residuals of Equation (2) in order to test the stability. The CUSUM test is based on the cumulative sum of recursive residuals while CUSUMSQ test is based on the squared recursive residuals. If and only if the plot of the CUSUM and CUSUMSQ statistics stays within $5 \%$ significant level, then the long-run and short-run coefficient estimates are stable.

\section{Empirical Results and Stability Tests}

Quarterly data from 2006Q1 to 2016Q1 were employed to carry out the empirical analysis. Nominal M1 and M2 are used as monetary aggregate. Two steps are involved in the empirical tests. First, we impose different lags on each first differenced variable in (2) and carry out the F-test. Table 1 reports the results of the F-tests for M1 and Table 2 reports the results of the F-tests for M2 when 2, 4 and 6 lags are imposed on each first differenced variable in (2). 
Table 1. The Result of F-test and Ecm (-1) for M1.

\begin{tabular}{ccccccc}
\hline \multicolumn{5}{c}{ M1 Money Aggregate } \\
\hline Lags & Calculated F-test & Optimal lags & Ecm $(-1)$ & F-test at Optimal lags & 95\% Lower Bound & 95\% Upper Bound \\
\hline 2 & $3.5064^{*}(0.021)$ & $(2,0,2,1)$ & $-0.2070^{\star *}(0.009)$ & 6.2439 & 3.5314 & 4.7607 \\
4 & $2.0734(0.135)$ & $(1,3,3,0)$ & $-0.1091(0.147)$ & 7.0495 & 3.5866 & 4.8454 \\
6 & $1.4315(0.346)$ & $(2,4,0,0)$ & $0.1197(0.118)$ & 4.1642 & 3.6207 & 4.8629 \\
\hline
\end{tabular}

Note: ${ }^{*}$ indicates $5 \%$ significance. ${ }^{* *}$ indicates $1 \%$ significance. $\mathrm{Ecm}(-1)$ is the error-correction term.

Table 2. The Result of F-test and $\operatorname{Ecm}(-1)$ for M2.

\begin{tabular}{ccccccc}
\hline \multicolumn{7}{c}{ M2 Money Aggregate } \\
\hline Lags & Calculated F-test & Optimal lags & $\mathrm{Ecm}(-1)$ & F-test at Optimal lags & $95 \%$ Lower Bound & $95 \%$ Upper Bound \\
\hline 2 & $5.2460^{* *}(0.003)$ & $(1,2,1,1)$ & $-0.2468^{* *}(0.000)$ & 9.2807 & 3.5314 & 4.7607 \\
4 & $0.8486(0.516)$ & $(1,3,4,0)$ & $-0.5086^{* *}(0.000)$ & 9.7501 & 3.5866 & 4.8454 \\
6 & $3.3342(0.109)$ & $(1,2,6,0)$ & $-0.2698^{* *}(0.000)$ & 9.1425 & 3.6207 & 4.8629 \\
\hline
\end{tabular}

Note: ${ }^{\star}$ indicates $5 \%$ significance. ${ }^{\star *}$ indicates $1 \%$ significance. Ecm $(-1)$ is the error-correction term.

From Table 1 and Table 2, it is clear that only when 2 lags are imposed on each first differenced variables in (2), the calculated $F$ test for monetary aggregate (M1 or M2) is significant. In the remaining cases, cointegration among the variables of M1 and M2 money demand function is rejected. However, as pointed out by [10], the above results may be considered preliminary since lags are selected arbitrarily. We decide to overcome the arbitrary nature of lag selection and employ a selection procedure to select the appropriate number of lags on each variable. The selection procedure employed in this study is Akaike Information Criterion (AIC). That means we employ AIC to select the optimum number of lags for each variable in Equation (2) after imposing maximum of 2, 4, and 6 lags on each first differenced variable in (2).

The optimal lags, F-test with optimal lags, and the values of error correction terms for M1 are reported in Table 1. The optimal lags, F-test with optimal lags, and the values of error correction terms for M2 are reported in Table 2. From the results of F-test with optimal lags in Table 1, the values of F-test with optimal lags are greater than 95\% upper bound value for M1 with 2 lags and with 4 lags, while the error correction term is only negative and significant for M1 with 2 lags. From the Table 2, the F-test with optimal lags for M2 are all greater than the 95\% upper bound, and the error correction terms are all negative and significant, supporting cointegration. It seems that there is stronger evidence of cointegration when M2 money aggregate is used.

Since one of the main objectives of this paper is to test the long-run stability, we only report the long-run estimation here. Table 3 reports the long-run coefficient estimates for M1 aggregate, while Table 4 reports the long-run estimates for M2 aggregate.

From Table 3, it is clear the estimations of the equation for M1 money aggregate are quite different when different lags are imposed on each first differenced 
Table 3. Long-run coefficient estimates for M1.

\begin{tabular}{|c|c|c|c|c|c|}
\hline \multicolumn{6}{|c|}{ M1 Money Aggregate } \\
\hline Lags & & $Y$ & $\pi$ & $E X$ & Inpt \\
\hline \multirow{3}{*}{2} & Coefficient & $0.0041^{\star}$ & -0.0040 & $-0.2575^{\star}$ & $18.4744^{* *}$ \\
\hline & (T-Ratio) & $(2.1234)$ & $(-0.2253)$ & $(-2.1000)$ & $(19.8715)$ \\
\hline & [Prob.] & {$[0.042]$} & {$[0.823]$} & {$[0.044]$} & {$[0.000]$} \\
\hline \multirow{3}{*}{4} & Coefficient & 0.0011 & 0.0153 & -0.1748 & $18.3202^{\star *}$ \\
\hline & (T-Ratio) & $(0.2743)$ & $(0.5453)$ & $(-0.8384)$ & $(12.2084)$ \\
\hline & [Prob.] & {$[0.786]$} & {$[0.590]$} & [0.409] & {$[0.000]$} \\
\hline \multirow{3}{*}{6} & Coefficient & 0.0049 & 0.0658 & $-1.0491^{\star}$ & $22.6567^{* *}$ \\
\hline & (T-Ratio) & $(1.8713)$ & $(1.6366)$ & $(-2.1632)$ & (7.1990) \\
\hline & [Prob.] & 0.073 & {$[0.114]$} & {$[0.040]$} & {$[0.000]$} \\
\hline
\end{tabular}

Note: ${ }^{*}$ indicates $5 \%$ significance. ${ }^{*}$ indicates $1 \%$ significance.

Table 4. Long-run coefficient estimates for M2.

\begin{tabular}{cccccc}
\hline \multicolumn{5}{c}{ M2 Money Aggregate } \\
\hline Lags & & $Y$ & $\pi$ & $E X$ & Inpt \\
\hline \multirow{4}{*}{2} & Coefficient & $0.0090^{* *}$ & $-0.0176^{* *}$ & $-0.2667^{* *}$ & $19.0722^{* *}$ \\
& (T-Ratio) & $(13.3108)$ & $(-3.2604)$ & $(-7.0426)$ & $(58.1041)$ \\
& [Prob.] & {$[0.000]$} & {$[0.003]$} & {$[0.000]$} & {$[0.000]$} \\
& & & & & \\
& Coefficient & $0.0086^{* *}$ & 0.0036 & $-0.2647^{* *}$ & $19.0016^{* *}$ \\
& (T-Ratio) & $(15.9322)$ & $(0.9749)$ & $(-10.8008)$ & $(83.2669)$ \\
& [Prob.] & {$[0.000]$} & {$[0.339]$} & {$[0.000]$} & {$[0.000]$} \\
& & & & & \\
& Coefficient & $0.0078^{* *}$ & -0.0038 & $-0.2765^{* *}$ & $19.2711^{* *}$ \\
& (T-Ratio) & $(8.1092)$ & $(-0.4272)$ & $(-4.6320)$ & $(39.8403)$ \\
& [Prob.] & {$[0.000]$} & {$[0.673]$} & {$[0.000]$} & {$[0.000]$} \\
\hline
\end{tabular}

Note: ${ }^{*}$ indicates $5 \%$ significance. ${ }^{* *}$ indicates $1 \%$ significance.

variable in (2). When 2 lags are imposed, the coefficient of $Y$ carries expected positive sign and significant and the coefficient of exchange is negative and significant. When 4 lags are imposed, the coefficients for $Y, \pi$ and Ex are all insignificant. However, when 6 lags are imposed, only the coefficient of exchange rate is negative and significant.

From Table 4, in contract to the results of M1, the estimation of the equation for M2 monetary aggregate is quite consistent. The coefficient of $Y$ all carries expected positive sign and significant. The coefficients of exchange rate are all negative and significant, suggesting strong currency substitution. Further, the effect of currency substitution is in favor of foreign currency rather than wealth effect when Chinese Yuan depreciates. The coefficient of inflation carries expected negative sign and significant for only one case (with 2 lags). It seems both the real income and exchange rate play an important role in the demand for M2 monetary aggregate in China. 
After the long run estimates, we examine the stability by applying CUSUM and CUSUMSQ tests for both M1 and M2. The stability results are reported in Figure 1 and Figure 2. It seems it is stable for all cases we tested.

These results are quite interesting since they are different from the results in [1]. First, M2 is cointergated with its determinants in all cases and M1 is only cointegrated in some cases in present study, while both M1 and M2 are cointegrated in [1]. Second, M2 is stable in the current study, while the stability of M2 is questionable in [1]. Third, we detect strong currency substitution for M2 money aggregate in present study, while the coefficient for exchange rate is insignificant in [1]. The main reason for the different results is: more recent data are chosen to analyze demand for money in China in current study and the characteristics of money demand in China may be different now given the ongoing banking system reform and the exchange reform in 2005 .

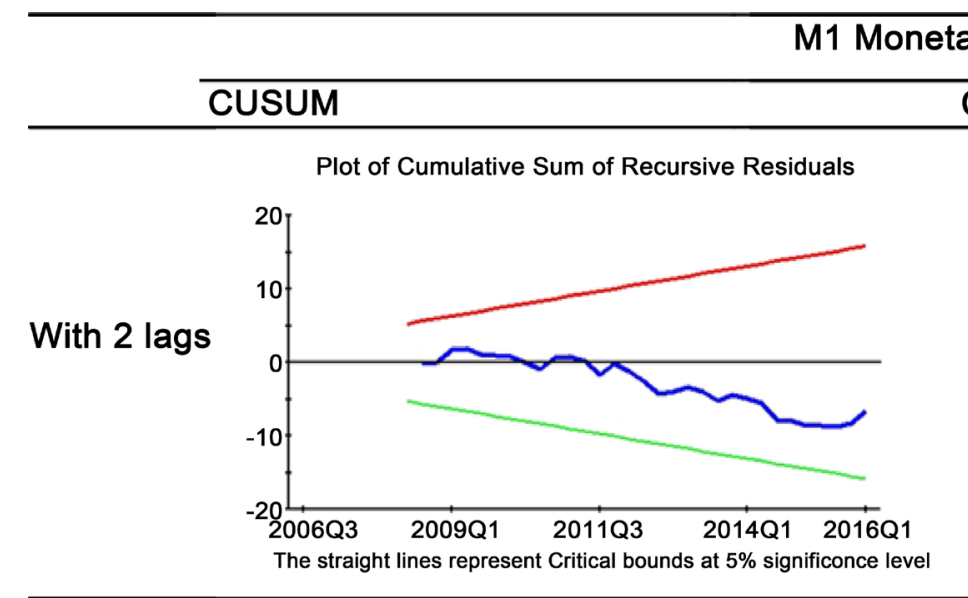

ary Aggregate CUSUMQ

Plot of Cumulative Sum of Squares of Recursive Residuals

Plot of Cumulative Sum of Recursive Residuals

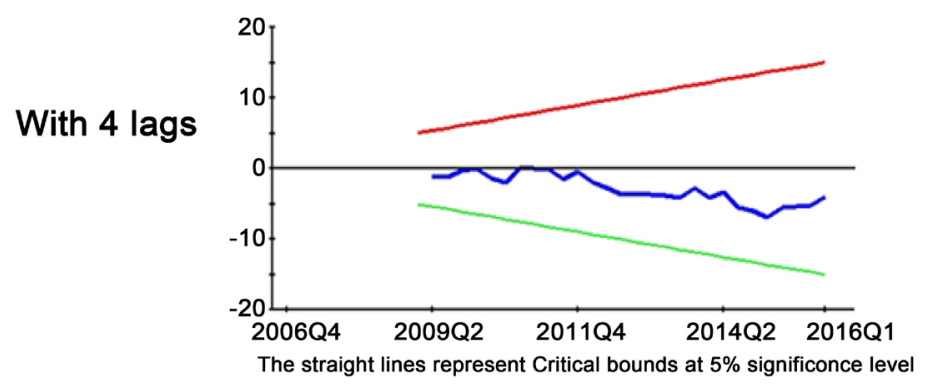

Plot of Cumulative Sum of Recursive Residuals

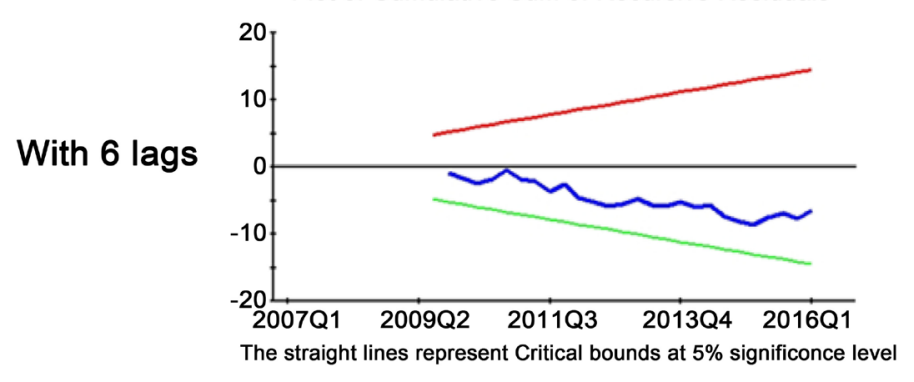

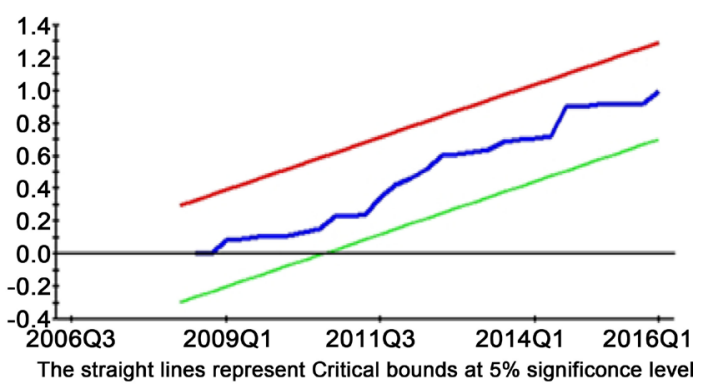

Plot of Cumulative Sum of Squares of Recursive Residuals

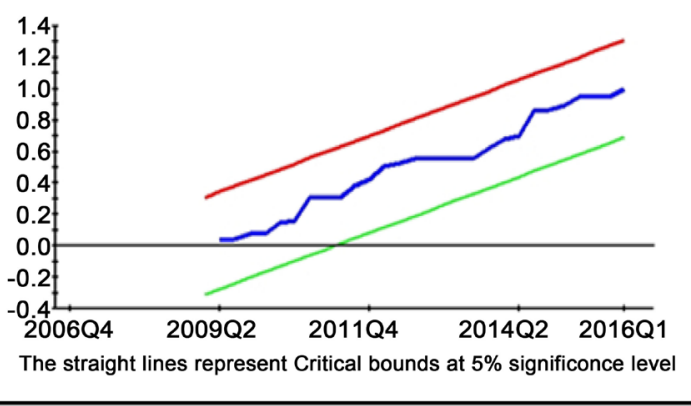

Plot of Cumulative Sum of Squares of Recursive Residuals

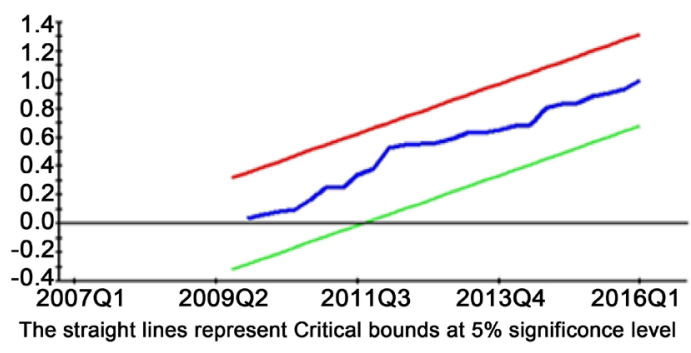

Figure 1. Stability Test Results for M1. 


\section{M2 Monetary Aggregate}

CUSUM CUSUMQ

Plot of Cumulative Sum of Recursive Residuals

With 2 lags

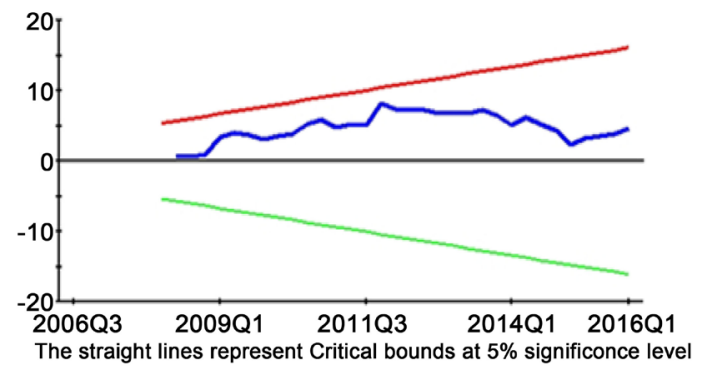

Plot of Cumulative Sum of Squares of Recursive Residuals

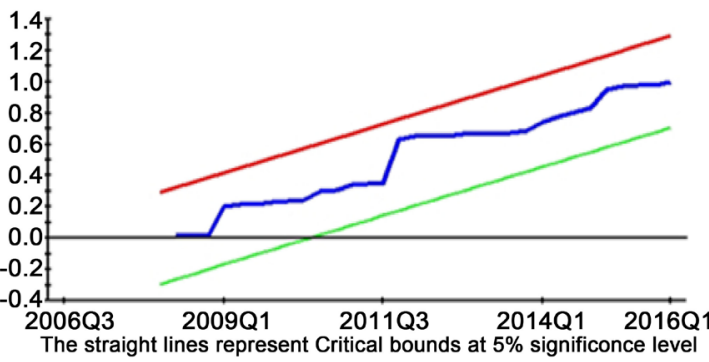

Plot of Cumulative Sum of Recursive Residuals

With 4 lags

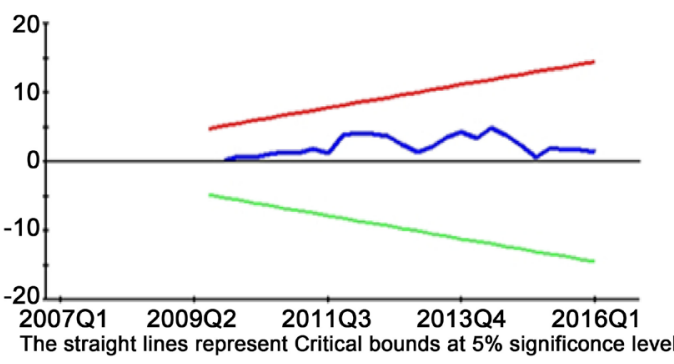

Plot of Cumulative Sum of Squares of Recursive Residuals

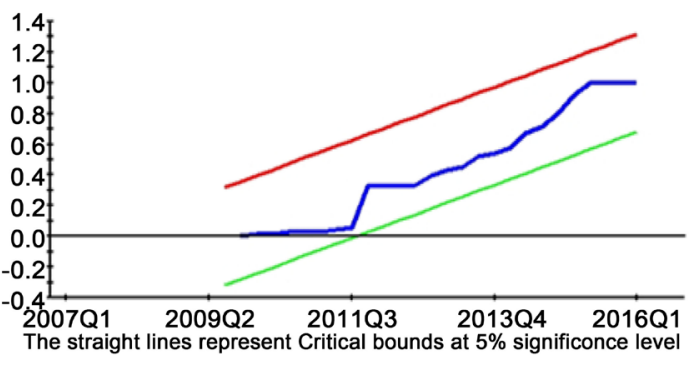

Plot of Cumulative Sum of Recursive Residuals

With 6 lags

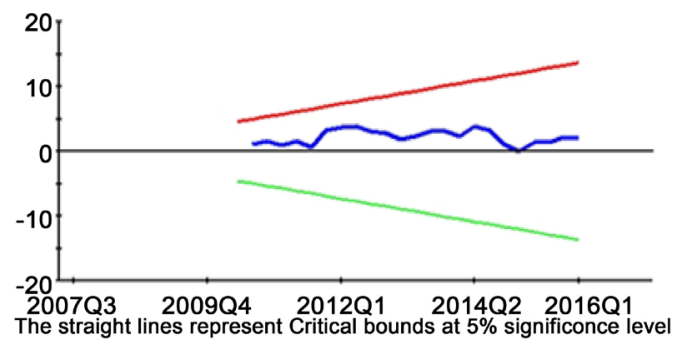

Plot of Cumulative Sum of Squares of Recursive Residuals

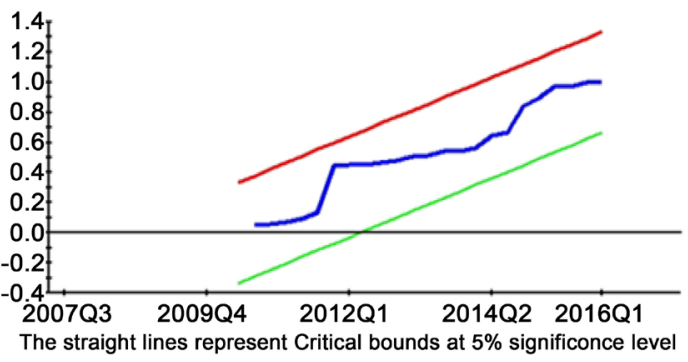

Figure 2. Stability test results for M2.

\section{Conclusions}

In the present study, we employ the quarterly data after China's exchange rate reform in 2005 to study demand for money in China. We include the exchange rate into the equation in order to examine possible currency substitution given the ongoing financial reform and the exchange rate reform in 2005.

We show that the cointegration of M1 monetary aggregate with domestic income, inflation rate as well as exchange rate is doubtful, while M2 money aggregate is cointegrated with these determinants. Moreover, for M2 monetary aggregate, the coefficients of domestic income are positive and significant in all cases while the coefficients of exchange rate are all negative and significant, suggesting strong currency substitution. The CUSUM and CUSUMQ test with cointegration analysis revealed that M2 aggregate is stable in all cases. Based on 
the cointegration results, M2 serves as better money aggregate for China. This result is different from the finding in [3]. One Policy implication is: the monetary authority should target M2 rather than M1 now and should also pay attention to the currency substitution in order to carry out an effective monetary policy in China.

We use inflation rate, rather than interest rate to measure the opportunity costs of holding money in China in current study. Further research may investigate if interest rate is appropriate measurement using recent data. However, one may have to wait a little longer to study it for two reasons. 1) The interest rate is not completely market-oriented yet. 2) Compared to the interest rate, the inflation rate is still quite high in China, which makes inflation rate a better measurement of opportunity costs of holding money in China. It may take some time for the Chinese government to control the inflation rate. Further research could use different cointegration method to estimate the model in order to see if the findings are robust. Further research could also test the effect of exchange rate on other macro variable using the data after China adopted the managed floating exchange rate regime and discuss if China should move to completely floating exchange rate regime.

\section{References}

[1] Bahmani-Oskooee, M. and Y. Wang (2007) How Stable Is the Demand for Money in China? Journal of Economic Development, 32, 21-33.

[2] Huang, C. (2000) Economic Reform and the Stability of Long-Run Demand for Money in China: Some Results from Co-Integration Tests. In: Cook, S., Yao, S. and Zhuang, J., Eds., The Chinese Economy under Transition, Palgrave Macmillan, UK, 276-296. https://doi.org/10.1057/9780230288164_15

[3] Lee, C. and Chang, C. (2012) The Demand for Money in China: A Reassessment Using the Bounds Testing Approach. Romanian Journal of Economic Forecasting, $15,74-94$.

[4] Mehrotra, A.N. (2008) Demand for Money in Transition: Evidence from China's Disinflation. International Advances in Economic Research, 14, 36-47. https://doi.org/10.1007/s11294-007-9129-4

[5] Zuo, H. and Park, S.Y. (2011) Money Demand in China and Time-Varying Cointegration. China Economic Review, 22, 330-343.

[6] Bahmani-Oskooee, M. and Bohl, M. (2000) German Monetary Unification and the Stability of Long-Run German Money Demand Function. Economics Letters, 66, 203-208.

[7] Okazaki, K. (2007) Banking System Reform in China: the Challenges of Moving toward a Market-Oriented Economy. www.rand.org

[8] Engle, R.F. and Granger, C.W.J. (1987) Co-Integration and Error Correction: Representation, Estimation, and Testing. Econometrica, 55, 251-276. https://doi.org/10.2307/1913236

[9] Pesaran, H.M., Shin, Y. and Smith, R.J. (2001) Bounds Testing Approaches to the Analysis of Level Relationships. Journal of Applied Econometrics, 16, 289-326. https://doi.org/10.1002/jae.616

[10] Bahmani-Oskooee, M. (2001) How Stable Is M2 Money Demand Function in Japan? Japan and the World Economy, 13, 455-461. 
Submit or recommend next manuscript to SCIRP and we will provide best service for you:

Accepting pre-submission inquiries through Email, Facebook, LinkedIn, Twitter, etc. A wide selection of journals (inclusive of 9 subjects, more than 200 journals)

Providing 24-hour high-quality service

User-friendly online submission system

Fair and swift peer-review system

Efficient typesetting and proofreading procedure

Display of the result of downloads and visits, as well as the number of cited articles Maximum dissemination of your research work

Submit your manuscript at: http://papersubmission.scirp.org/

Or contact me@scirp.org 